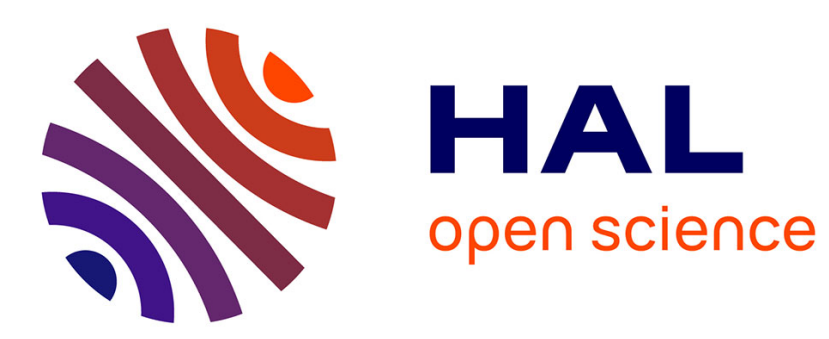

\title{
The influence of wilting on wheat silage
}

\author{
G. Ashbell, Non Renseigné, D. Sklan
}

\section{To cite this version:}

G. Ashbell, Non Renseigné, D. Sklan. The influence of wilting on wheat silage. Agronomie, 1986, 6

(5), pp.459-462. hal-00884897

\section{HAL Id: hal-00884897 \\ https://hal.science/hal-00884897}

Submitted on 1 Jan 1986

HAL is a multi-disciplinary open access archive for the deposit and dissemination of scientific research documents, whether they are published or not. The documents may come from teaching and research institutions in France or abroad, or from public or private research centers.
L'archive ouverte pluridisciplinaire HAL, est destinée au dépôt et à la diffusion de documents scientifiques de niveau recherche, publiés ou non, émanant des établissements d'enseignement et de recherche français ou étrangers, des laboratoires publics ou privés. 


\title{
The influence of wilting on wheat silage
}

\author{
G. ASHBELL, H. H. THEUNE (*) \& D. SKLAN $\left(^{* *}\right)$ \\ Agricultural Research Organization, The Volcani Center, P.O. Box 6, Bet Dagan 50250, Israel
}

SUMMARY

Wheat plants at shooting and flowering maturation stages were cut and wilted to $36 \%$ dry matter (DM). The wheat was ensiled for 90 days and exposed to air for a further 7 days. Changes in chemical composition and microfloral count were determined for fresh and wilted plants after ensiling and after exposure to air. Special attention was paid to changes in amino acid content.

Additional key words : Microflora, aminoacid content, silage, wheat, wilting.

RÉSUMÉ

\section{Influence du préfanage sur l'ensilage de blé}

Des plantes de blé aux stades montaison et floraison ont été coupées et préfanées jusqu'à $36 \mathrm{p}$. 100 de matière sèche. Le blé a été ensilé pendant 90 jours et ensuite exposé à l'air durant 7 jours de plus. Les changements dans la composition chimique et dans celle de la microflore ont été déterminés sur les plantes fraîches et préfanées après ensilage et après exposition à l'air.

Une attention spéciale a été portée aux modifications de teneur en acides aminés.

Mots clés additionnels : Microflore, teneur en acides aminés, ensilage, blé, préfanage.

\section{INTRODUCTION}

Wilting is often applied to the yields from the ensiling process of wet forage to increase the dry matter (DM) content. Suitable DM contents for ensiling are between 28 and $34 \%$ (McCullough, 1978). Wilting causes the following changes on ensiling : an increase in $\mathrm{pH}$, reduction in bacteria and reduction in lactic and butyric acid contents (STIRLING, 1951). Wilting to more than $30 \%$ DM limits development of Clostridium bacteria (WEISBACH et al., 1974).

Additional changes in freshly cut plants effected by wilting include deamination, which results in loss of protein. This is caused in the freshly cut plant by plant enzymes, and ceases at between 40 and $45 \%$ DM. Deamination in the silage is usually due to clostridial activity and this can be limited by raising the DM above $30 \%$ before ensiling (MACPHERSON, 1952).

STEWART \& BOGGESS (1977) revealed that wilting increases synthesis of proline from glutamate and

$\left(^{*}\right)$ Institute of Grassland and Forage Research, Federal Research Center of Agriculture (F.A.L.) Braunschweig, Federal Republic of Germany.

$\left({ }^{* *}\right)$ Faculty of Agriculture, The Hebrew University of Jerusalem, Rehovot 76100 , Israel. stimulates conversion of arginine and ornithine to proline in the freshly cut plant. HONIG (1979) found that respiration losses of cut herbage increased as temperature increased and decreased as DM increased.

However, very little information has been published on the effect of wilting of wheat on the nutritive constituents during the ensiling process and after exposure to air.

\section{MATERIALS AND METHODS}

Wheat plants (var. 'Kranich') were harvested for two consecutive years at the shooting and flowering stages of maturation, though due to similarity in composition there was no justification for separation of the results of analyses and the results given are the mean of both stages. Part of the material was wilted in a ventilated shed for $24 \mathrm{~h}$. The wheat plants were then chopped and ensiled. Ensiling was carried out at $30{ }^{\circ} \mathrm{C}$ for both wilted and fresh material in five 1.5 liter sealed jars with a fermentation lock (J. Weck GmbH u. Co., Über Oflingen, W. Germany).

These jars were pooled at the end of the fermentation period. After 90 days' fermentation, aerobic exposure (AE) was undertaken at $30{ }^{\circ} \mathrm{C}$ for 7 days as 
described by WOOLFORD et al. (1977). According to this method, uncompressed sub-samples of 3 liters were held in a heat insulation chamber, at constant temperature $\left(30^{\circ} \mathrm{C}\right)$. Air was passed through the silage being tested and continued through a wash bottle containing $\mathrm{KOH}$ solution. The $\mathrm{CO}_{2}$ engendered by the silage was trapped and could be titrated. Representative samples from fresh, wilted and silage material and at the end of the AE period were taken for analysis or dried in a freeze-drying unit (Type Epsilon, Martin Christ, 3360 Ostenrode am Harz, W. Germany). Dry matter was determined by toluene distillation (DEWAR \& McDONALD, 1961). Nitrogen (N) was determined by the Kjeldahl method, and crude protein (CP) was calculated by multiplying $\mathrm{N}$ by 6.25. Ammonia- $\mathrm{N}$ was determined by using an ammonia electrode (Orion Research Inc., Cambridge, MA, U.S.A.). In this method, $10 \mathrm{~g}$ of silage was mixed with $90 \mathrm{ml}$ of distilled water for $3 \mathrm{mn}$ and then filtered. Twenty $\mathrm{ml}$ of the filtrate was used for analysis. A calibration curve was obtained using a standard concentration of ammonium-chloride. Free amino acids (FAA) were extracted after homogenization in an ice-cold mixture of acetone and water $(7: 3 \mathrm{v} / \mathrm{v})$ and analyzed directly. The bound amino acids (AA) in the remaining material were analyzed after separating FAA and hydrolysis $\left(\mathrm{HCl}, 6 \mathrm{M}, 24 \mathrm{~h}, 120^{\circ} \mathrm{C}\right)$. Total AA were determined from freeze-dried material using an Amino Acid Analyzer (Biotronic Wissenschaftliche Gerate GmbH, model L.C. 6000).

Total nitrogen analysis was also carried out on the solution prepared for the AA analysis, to verify recovery. Water-soluble carbohydrates (WSC) were determined as described by BOMMER (1959). Ethanol, lactic acid and volatile fatty acid (VFA) concentrations were determined by gas chromatography (THEUNE, 1978). Crude fiber (CF), ash and ether extract were determined according to AOAC methods (AOAC, 1980). In vitro organic matter digestibility (IVOMD) was determined according to TILLEY \& TERRY (1963). Buffering capacity was determined according to McDONALD \& HENDERSON (1962).

Silage microflora were determined quantitatively from serial dilutions of culture on selective media ; for lactic acid bacteria (Rogosa agar), yeasts and moulds (Martins Medium), proteolytic bacteria (calcium caseinate agar) and coliform bacteria (violet red bile agar). Duplicate samples were examined in each case.

\section{RESULTS}

Analytical data and microfloral counts of the wilted and unwilted wheat plants, fresh and silage are given in table 1 . The main effect of wilting was to increase the DM content by $65 \%$. The high DM decreased the fermentation products in the silage. The microfloral counts of the wilted silage were lower for moulds and proteolytic bacteria, but higher for coliform bacteria than unwilted plants. Changes in nutritive ingredients and microbial counts due to $\mathrm{AE}$ in silage made from

TABLE 1

Nutritive constituents and microbial counts of wheat plants at early maturation (shooting and flowering) for fresh and silage material, wilted and unwilted (mean $\pm S D$ ).

Composition et flore microbienne du blé plante entière lors des tout premiers stades de maturation (montaison et floraison) avant ou après ensilage, préfané ou non préfané.



* Part of the ash may have been due to the presence of soil fraction.

Une partie des cendres est peut-être due à la présence de terre sur les plantes.

** Lactic acid $0.1 \mathrm{~N}$ required to bring the plant extract to $\mathrm{pH} 4$, expressed in $\mathrm{g}$ lactic acid per $100 \mathrm{~g} \mathrm{DM}$.

Quantité d'acide lactique $0,1 \mathrm{~N}$ nécessaire pour abaisser l'extrait aqueux de la plante à $\mathrm{pH} 4$, exprimée en g d'acide lactique pour $100 \mathrm{~g}$ de matière sèche. 
unwilted and wilted wheat plants are shown in figure 1. Comparison of the $\mathrm{pH}$ between silage and $\mathrm{AE}$ and between the wilted and unwilted silages in the $\mathrm{AE}$ showed that the $\mathrm{pH}$ of the $\mathrm{AE}$ increased, and the $\mathrm{pH}$ of unwilted material was higher than that of the wilted.

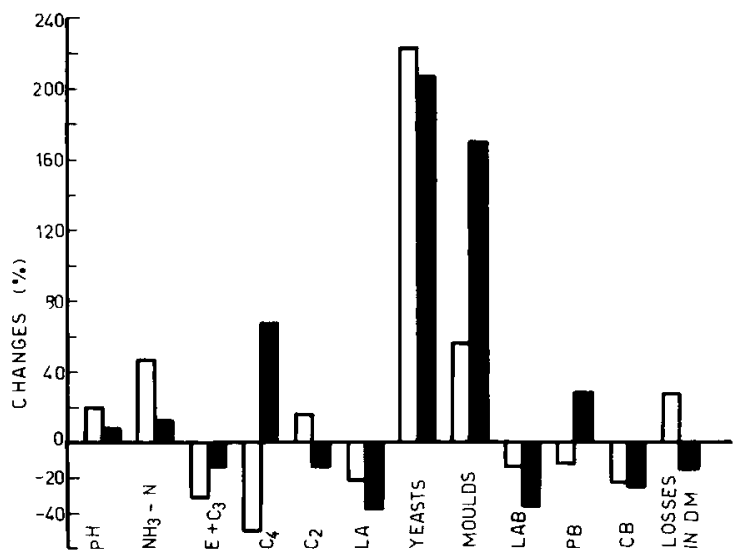

Figure 1

Changes in nutritive constituents and microbial counts due to aerobic exposure in silage made from unwilted and wilted wheat plants. Changes are given as percent in comparison with silage before aeration.

$E=$ Ethanol; $C_{3}=$ Propionic acid; $C_{4}=$ Butyric acid; $C_{2}=$ Acetic acid $;$ L.A. = Lactic acid $;$ L.A.B. = Lactic acid bacteria $;$ P.B. $=$ Proteolytic bacteria $;$ C.B. $=$ Coliform bacteria.

Modifications des caractéristiques fermentaires et de la flore microbienne après exposition à l'air, des ensilages de blé préfané et non préfané. Les données sont établies en pourcentage, en comparaison avec les ensilages avant exposition à l'air.
unwilted material
matériel non préfané

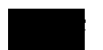
wilted material
matériel préfané

Ammonia-N was higher in the unwilted AE than the wilted. The reduction in ethanol and fatty acids during aeration of the silage was greater in the wilted material. However, the decrease in lactic acid was double that of the unwilted.

Losses in the wilted wheat during the ensiling period were $30 \%$ less than in the unwilted, and $53 \%$ less in comparison with the unwilted wheat during the AE.

Total and free amino acid nitrogen in the wilted and unwilted wheat plant, silage and $\mathrm{AE}$, are given in figure 2. Before ensiling the concentration of TAA in the wilted wheat plants increased by $18 \%$ in comparison with the unwilted, while the FAA percentage increased by 2.7 times in comparison with unwilted wheat plants. The amino acid nitrogen of the whole wheat plant at the shooting and flowering maturation stages : fresh, ensiled and after aerobic exposure are given in table 2 .

Changes in amino acids due to wilting are shown in figure 3. The most pronounced increase in AAs due to wilting were, in the fresh plant: asparagine, glutamine and serine; in the silage : glutamine and tyrosine; and in the $\mathrm{AE}$ : asparagine and lysine. Methionine seemed to be negatively affected by wilting.

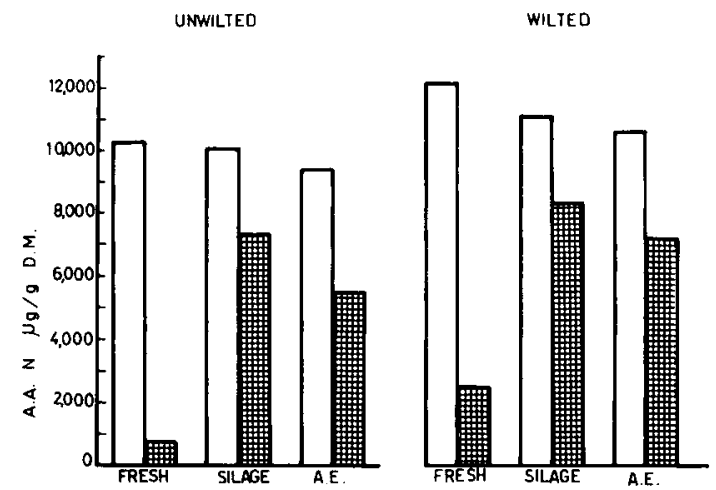

Figure 2

Total and free amino acid nitrogen at early maturation stages of unwilted and wilted wheat plants, in silage and in aerated silage.

Azote des acides aminés totaux et des acides aminés libres dans les tout premiers stades de maturation des plantes de blé préfanées et non préfanées, après ensilage et après exposition à l'air libre.

\section{total amino acids acides aminés totaux}

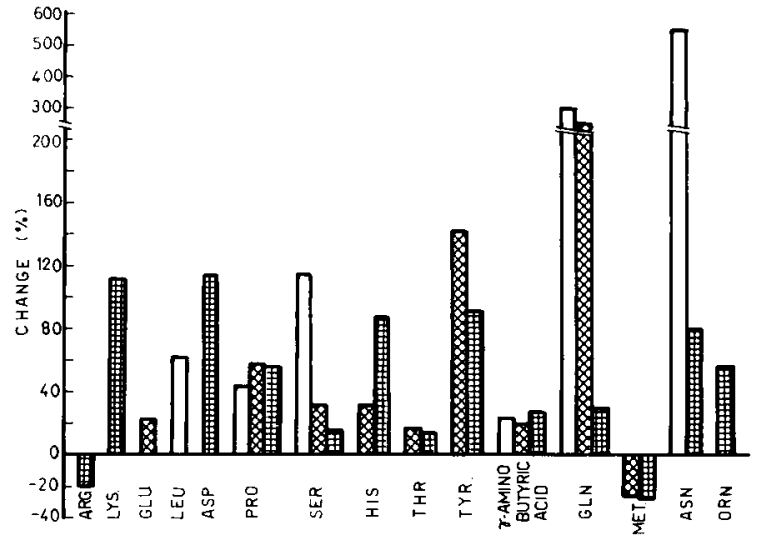

Figure 3

Changes in amino acids in wilted wheat plant, in the silage and after aeration in comparison with unwilted material (changes of less than $\pm 10 \%$ are not shown).

Modification des teneurs en différents acides aminés dans les plantes de blé préfanées, après ensilage et après exposition à l'air, par comparaison à la plante fraîche. Les changements de moins de $\pm 10 \%$ ne sont pas indiqués.

$\begin{aligned} & \text { wilted wheat plants } \\ & \text { blé préfané } \\ & \text { aerated silage } \\ & \text { ensilage aéré }\end{aligned}$
且列

\section{CONCLUSION}

During wilting of plants respiration continues, and in this process $\mathrm{CO}_{2}$ is released and sugar content decreases (MAY-BRAUN \& HARRIS, 1975). In wilted wheat plants a $6 \%$ reduction in the WSC was observed. This resulted only in a $2 \%$ decrease in in vitro digestibility. Ammonia-N was also higher in the wilted wheat plant and FAA were $8.3 \%$ higher than in the unwilted. AA composition in the wilted wheat was similar to that in the unwilted except for an increase in asparagine, glutamine, proline and leucine and a decrease in glutamic acid and arginine in the wilted plant. STEWART \& BOGGESS (1977) reported the 
TABLE 2

Amino acid nitrogen of whole wheat plant at early maturation stages (shooting and flowering) fresh, ensiled and after aerobic exposure. Results are given as \% of nitrogen in DM (mean $\pm S D)$. The free form is given as \% of the total amino acid.

Azote des acides aminés de la plante entière de blé dans les premiers stades de maturation (montaison et floraison), frais, ensilés et après exposition à l'air. Les résultats sont donnés en pourcentage d'azote dans la matière sèche (moyenne \pm SD). La forme libre est donnée en pourcentage du total des acides aminés.

\begin{tabular}{|c|c|c|c|c|c|c|c|c|c|c|c|c|c|c|c|c|c|c|c|c|}
\hline Source & Arg. & Lys. & Gli. & Ala. & Leu. & Gly. & Asp. & Val. & Pro. & Ser. & His. & Thr. & Ile. & Phe. & Tyr. & $\begin{array}{c}\gamma \\
\text { Ami } \\
\text { but. } \\
\text { Acid }\end{array}$ & Gln. & Met. & Asn. & Orn. \\
\hline Fresh: total & 8.6 & 5.7 & 4.2 & 4.3 & 3.7 & 3.4 & 3.5 & 3.1 & 2.9 & 2.4 & 2.6 & 2.4 & 2.2 & 2.2 & 1.1 & 0.7 & 0.5 & 0.5 & 0.3 & 0.1 \\
\hline $\mathrm{SD}$ & 1.8 & 0.6 & 0.4 & 0.3 & 0.4 & 0.3 & 0.2 & 0.3 & 0.6 & 0.2 & 0.4 & 0.3 & 0.3 & 0.3 & 0.2 & 0.2 & 0.2 & 0.1 & 0.03 & 0.01 \\
\hline$\%$ in free form & 2.1 & 2.7 & 2.9 & 18.5 & 3.4 & 2.8 & 4.0 & 5.1 & 13.1 & 10.0 & 3.8 & 6.6 & 3.9 & 3.5 & 4.7 & 86.1 & 100 & 1.8 & 100 & 34.5 \\
\hline Silage: total & 1.4 & 5.1 & 1.9 & 4.8 & 3.9 & 3.8 & 3.2 & 3.2 & 2.8 & 1.6 & 1.7 & 2.3 & 2.2 & 2.2 & 0.5 & 3.0 & 0.03 & 0.8 & 1.9 & 2.2 \\
\hline SD & 0.2 & 1.0 & 0.04 & 0.5 & 0.5 & 0.4 & 0.8 & 0.4 & 0.2 & 0.3 & 0.3 & 0.06 & 0.4 & 0.4 & 0.07 & 0.8 & 0.01 & 0.2 & 0.3 & 0.1 \\
\hline$\%$ in free form & 0 & 68.5 & 49.6 & 76.4 & 74.4 & 70.3 & 69.0 & 73.4 & 79.6 & 75.7 & 64.5 & 74.7 & 75.4 & 72.4 & 51.4 & 97.6 & 100 & 85.5 & 100 & 81.6 \\
\hline$A E$ : total & 2.2 & 4.1 & 2.4 & 4.8 & 3.8 & 3.6 & 3.0 & 3.1 & 2.5 & 1.7 & 1.1 & 2.2 & 2.1 & 2.0 & 0.6 & 2.7 & 0.1 & 0.6 & 1.0 & 1.4 \\
\hline SD & 0.1 & 0.2 & 0.1 & 0.4 & 0.4 & 0.4 & 0.7 & 0.3 & 0.04 & 0.03 & 0 & 0.1 & 0.2 & 0.2 & 0.05 & 0.6 & 0.02 & 0.1 & 0.02 & 0.05 \\
\hline$\%$ in free form & 0 & 47.5 & 37.4 & 68.9 & 63.7 & 60.5 & 51.7 & 64.3 & 69.2 & 51.9 & 29.5 & 60.2 & 62.4 & 59.1 & 38.2 & 93.7 & 100 & 74.2 & 100 & 75.4 \\
\hline
\end{tabular}

conversion of arginine, glutamate and ornithine to proline during the wilting process and this is in accord with the above results. In the wilted silage, products of fermentation were $25 \%$ lower. WILKINS et al. (1971), MURDOCH (1960) and DONALDSON \& EDWARDS (1976) also reported that silage from wilted herbage contains less products of fermentation, and the amounts of lactic acid and butyric acid were low as in the present work. In contrast to our work MORGAN et al. (1980) reported a large decrease in lactic acid content in wilted clover and rye-grass silage. The main differences in microfloral count were for moulds in the wilted wheat silage. STIRLING (1951) reported that in silage from wilted herbage, bacterial development was delayed. The AA in silage from wilted wheat was similar to that from unwilted except for an increase in proline and tyrosine. This is expected in the light of the similar microbial pattern. The advantages to wilting were clear, especially when the silage was analyzed after AE. Changes in the unwilted silage were very large, $\mathrm{pH}$ and ammonia- $\mathrm{N}$ increased and the DM losses reached $8.1 \%$ (while in large scale silage seepage losses should be included, though these were not measured in this work), in comparison with a moderate increase in $\mathrm{pH}$ and ammonia- $\mathrm{N}$ in wilted aerated silage where DM losses were only $3.8 \%$.

Total losses on fermentation plus aerobic exposure in unwilted material reached $14.5 \%$ in comparison with the silage from wilted plants, which reached only $8.3 \%$ (non inclusive of field pre-wilting losses which were not measured). Harvesting of early maturation wheat could be very important in subtropical climates where the double-cropping system (wheat for silage in Winter, and cotton or corn in Summer) is possible and time is at a premium ; so it is possible to harvest early and decrease losses by wilting.

Reçu le 17 mai 1985. Accepté le 15 janvier 1986.

\section{REFERENCES BIBLIOGRAPHIQUES}

AOAC, 1980. Official Methods of Analysis of the Association of Official Analytical Chemists. Washington D.C., 125-142.

Bommer D. F., 1959. Die Bestimmung des Gesamtzucker im Pflanzenmaterial über Zeitpunkt und Verlauf der Blütendifferenzierung bei perennierenden Gräsern. Acker u. Pflanzenbau, 109, 95-118.

Dewar W. A., McDonald P., 1961. Determination of dry matter in silage by distillation with toluene. J. Sci. Food Agric., 12, 790-795.

Donaldson E., Edwards A. R., 1976. Feeding value of silage : silage made from freshly cut grass, wilted grass and formic acid treated wilted grass. J. Sci. Food Agric., 27, 536-544.

Honig H., 1979. Mechanical and respiration losses during prewilting of grass. Forage conservation in the 80 's. Br. Grassl. Soc. Symp. No. 11, Brighton, 76-87.

McCullough M. E., 1978. Fermentation of silage. A review. National Feed Ingredients Association (NFIA). West des Moines Iowa, U.S.A., 3-26.

McDonald P., Henderson A. R., 1962. Buffering capacity of herbage samples as a factor in ensiling. J. Sci. Food Agric., 13, 395-400.

Macpherson H. T., 1952. Changes in nitrogen distribution in crop conservation. II. Protein breakdown during wilting. J. Sci. Food Agric., 3, 365-367.

May-Brown R., Harris C. E., 1975. The respiration of drying grass leaves. Annu. Rep. Grassl. Res. Inst. Hurley, p. 49.

Morgan C. A., Edwards R. A., MeDonald P., 1980. Intake and metabolism studies with fresh and wilted silages. J. Agric. Sci. Camb., 94, 287-298.

Murdoch J. C., 1960. The effect of pre-wilting herbage on the composition of silage and its intake by cows. J. Br. Grassl. Sci., 15, 7073.

Stewart C. R., Boggess S. F., 1977. The effect of wilting on the conversion of arginine, ornithine and glutamine to proline in bean leaves. Plant Sci. Lett., 8, 147-153.

Stirling A. C., 1951. Bacterial changes in experimental laboratory silage. Proc. Soc. Appl. Bacteriol., 14, 151-156.

Theune H. H., 1978. Gaschromatographische Bestimmung der Kunzkettiger Fettsauren einschliesslich Äthanol und Milchsäure aus Garfutter. Ein Methodenvergleich. Landwirtsch. Forsch., 35, 547549.

Tilley J. M. A., Terry R. A., 1963. A two stage technique for the in vitro digestion of forage crops. Br. Grassl. Soc., 18, 104-111.

Weisbach F., Schmidt L., Heine E., 1974. Method of anticipation of the run of fermentation in silage marking, based on chemical composition of green fodder. Proc. 12th Int. Grassl. Moscow, 663673.

Wilkins R. J., Hutchison K. J., Wilson R. G., Harris C. E., 1971. The voluntary intake of silage by sheep. I. Interrelationship between silage composition and intake. J. Agric. Sci. Camb., 71, 531-532.

Woolford M. K., Honig H., Felson J. S., 1977. Untersuchungen über aerobischen Umsetzungen in Silage mit Hilfe einer Labortechnik. Das Wirtschafteigene Futter, 23, 10-22. 